\title{
Teaching Wadla Qəne Today: Observations from a Field Research in the Wadla Region
}

\author{
Christine Chaillot
}

The topic of this article, qane, has very much to do with the identity of the Ethiopian Orthodox Täwahədo Church and with its traditional oral education. Qəne (and wadla qane) is intrinsically part of this very ancient African church, officially established and proclaimed as state religion around $340 .{ }^{1}$ Qane is a poem composed in the Gə'əz language, the ancient language of Christian Ethiopia, and having a double meaning: the direct one also called wax (säm), and the hidden one called gold (wärq), referring to the goldsmith's technique of casting gold shapes within a wax mould. Whereas the writing in Gə`əz has virtually ceased, the oral composition and use of qane in Gə'əz continues to this day. ${ }^{2}$ In every major church, the person who has the ability to compose the qane and was trained and graduate from the qane school, creates a qane which is sung during the liturgy and other festive church services. ${ }^{3}$

Qəne is a kind of 'philosophical' or rather spiritual message composed in the Christian context of the Ethiopian Orthodox Church which is given and shared by all those who listen to it while it is sung in church. Wadla qane was created in the region of Wadla (in Wällo province today). ${ }^{4}$ It is the most important type of qane as it is the basis for all its other types.

1 Stuart Munro-Hay, "Christianity," in EAe 1 (2003): 717.

2 Getatchew Haile, "Gəəəz literature," in EAe 2 (2005): 738-739.

3 Ibid., $736-738$.

4 Wadla is a historical district in the Amhara region to the south of Lasta and to the west of

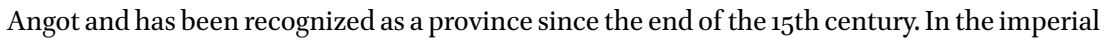
administrative division, it was paired with Dälanta in the administrative division (awrağğa) of Wadla Dälanta. Today it is one of the districts (wäräda) in the Amhara Region of northern eastern Ethiopia and is named after the former district which lays roughly in the same area. Part of the Sämen (nothern) Wällo zone, Wadla is bordered on the southeast by Dälanta, on the southwest by Dawənt, on the north by Mäqet, and on the northeast by Guba Lafto. Today the major and administrative town in Wadla is Kon. The majority of the inhabitants practice 
According to the tradition of the Ethiopian Orthodox Church, the wadla qəne is the original qəne created by Yoḥannəs Gäblawi. It is known to be particularly difficult on account of its grammar as well as its composition and interpretation, using many equivocal words, allusions and allegoric figures. The wadla qone was created in the region of Wadla. It is in that area ${ }^{5}$ that my research and interviews took place. Wadla is also the name of a type of church poetry (qəne) proper to the Ethiopian Orthodox Täwaḩədo Church. In fact, in the Ethiopian Orthodox tradition, Wadla region is said to be the place of origin of qəne. This was the reason of my interest to visit the place, in order to make interviews with qane teachers and to see what they could tell me about wadla qane, about the present situation of the teaching of qane in Wadla, including of wadla qane, and also to continue my quest for qəne and its teaching today. ${ }^{6}$ I also asked some questions about the qane teachers' life conditions and that of their students.

In the Ethiopian Orthodox Church, the students who study qane must also study other topics necessary to be trained as deacons and later as priests, first of all the Eucharistic liturgy (qaddase). They may also study liturgical music (zema), with daggw $a$ and șomä daggw $a$ and, according to their choice, for a better education, they can also study "the Books," that is of the Scriptures, the Old and New Testaments, the Church Fathers, the monastic literature, as well as ecclesiastical law. Thus, apart from poetry (qəne), other subjects studied in the traditional schools of the Ethiopian Orthodox Täwahədo Church will be named in this article such as the study of the liturgy (qaddase), chanting (zema), and exegesis or the Scripture (mäshaf $).^{7}$

Ethiopian Orthodox Christianity. The largest ethnic group reported in Wadla is the Amhara. Evgenia Sokolinskaia, "Wadla," in EAe 4 (2010): 1067.

5 See all the names quoted in this article (in a different transliteration) in the detailed map: Svein Ege, North Wälo 1:10o,ooo. Topographic and administrative map of North Wälo Zone, Amhara Region, Ethiopia (Trondheim: Norwegian University of Science and Technology, 2002). Such detailed maps with the names of Ethiopian Orthodox churches should be made for all Ethiopia.

6 See Christine Chaillot, The Ethiopian Orthodox Tewahedo Church Tradition. A Brief Introduction to Its Life and Spirituality (Paris: Inter-Orthodox Dialogue, 2002).

7 Sevir Chernetsov, "Traditional Christian education," in EAe 2 (2005):228-23o. See also: Chaillot, The Ethiopian Orthodox Church Tradition, 83-10o. For the Psalter (Dawit), see: Marilyn Heldman, "Psalter," in EAe 4 (2010): 231-233. For the liturgical music (zema), see: Anne Damon-Guillot, "Zema," in EAe 5 (2014): 174. For the liturgical books (daggwa), see: Habtemichael Kidane, "Dəggwa," in EAe 2 (2005): 123-124. For șomä daggwa, book used from the beginning of Lent to Easter, see: Habtemichael Kidane, "Șomä Dəggwa," in EAe 4 (2010): 691692. For Eucharistic liturgy (qaddase), see: Emmanuel Fritsch, "Qəddase," in EAe 4 (2010): 271-275. For theology and particularly exegesis of the Scripture (mäshaf) studied in the house of the books (mäșhaf bet) including the interpretation of the Old and New Testaments, of 
For the composition of the qane, specific grammatical, symbolic and other rules have to be maintained. ${ }^{8}$ Students may study all types of qane. The place where qane is taught is called "the house of the qane" (qane bet), one possible stage of the traditional church education in the Ethiopian Orthodox Church. Here the students focus on the theory and practice of the composition of qane. This study is difficult and can take many years. The student must first perfectly master the ancient church language, Gə`əz, by building up his vocabulary as well as composing and interpreting qəne. He must also profoundly study traditional Ethiopian Christian cultural, social, intellectual and educational and spiritual values. ${ }^{9}$ The students move from place to place, in order to study with some very good qane teachers of their choice.

The main historic centers for learning qəne are in Wadla (Wällo), Gonğ (Goğğam), Wašära (Damot/Goğğam), and also Gondär, each having distinct features..$^{10}$ As the learning of qane requires studying with different teachers and in different schools and places, students attend lessons with more than one master and in more than one school, in order to reach a high level of mastering qane..$^{11}$

According to Ethiopian Orthodox church scholars, the qane goes back to St. Yared, since short qane-like compositions are found in the dagg ${ }^{w} a$ (liturgical book with hymns and troparies) said to be composed by him. ${ }^{12}$ But, according to Habtemichael Kidane, St. Yared does not appear to have set the forms and meters for the genre thus his hymns cannot be defined as qane. ${ }^{13}$

the Church Fathers (liqawənt) and of the Monastic literature (mäșahəftä mänäkosat), see: Habtemichael Kidane, "Mäșhaf bet," in EAe 3 (2007), 834. For liturgical dance and its instrumental accompaniment ( $\left.a q^{w} a q^{w} a m\right)$, see: Kay Kaufman-Shelemay, "Aqwa $a q^{w} a m$," in EAe 1 (2003): 293. For the hymn called mästägaber, name also used as a hymn for the study of hymnody, see: Ezra Gebremedhin, "Mästägabə,", in EAe 3 (2007): 857-858. For arba'ət, element found in the daggw $a$ and șomä dagg ${ }^{w} a$, see: Habtemichael Kidane, "Arba'ət," in EAe 1 (2003): 317.

8 Habtemichael Kidane, "Qəne," in EAe 4 (2010): 283-285.

9 Ibid., 285 .

10 Ibid., 286 refering to Admasu Ğämbäre, Mäṣafä Qəne (Zəkrä Liqawənt) [The Book of the Qəne (The Memory of the Scholars)] (Addis Abäba, 1970/71), 10. At the 17th International Conference of Ethiopian Studies in Addis Abäba in November 2009, I presented another paper: Christine Chaillot, "How to Preserve the History of the Oral Traditional Education of the Ethiopian Orthodox Church in Ethiopia: Qəne teachers in Wašära, Gonğ, Sälalo and elsewhere in Goğğam," in African Studies. Forging New Perspectives and Directions, ed. Nina Pawlak, Hanna Rubinowska-Anioł and Izabela Will (Warszawa: Elipsa, 2016), 199-215.

11 Habtemichael Kidane, "Qəne bet," 286.

12 Yared is credited with the invention of Ethiopian church music and hymnody. Cf. Antonella Brita, "Yared," in $E A e{ }_{5}$ (2014): 26-28.

13 Habtemichael Kidane, “Qəne," 284. 
In fact, the beginning of the composition of qane is attributed to an early 15th-century scholar from Wadla named Yohannəs Gäblawi. ${ }^{14}$ This is the Wadla claim. Then there is the Gonğ claim (in Goğğam) - attributing the deed to a certain Täwanäy who flourished after the $15^{\text {th }}$ century. The line of Yohannəs Gäblawi is said to have precedence on other qəne teachers. Yohannəs Gäblawi is said to have acquired his qane inspiration during a spiritual meditation. Some say that he was born at Gäblon in Wadla (Lasta), and that his qəne flourished at the time of Emperor Zär’a Ya`əqob (1434-1468). Later Dədq Wäldä Maryam and Täwanäy formed two separate qəne styles-the wadla and the gonğ schools. The Wadla school was led by a succession of seven teachers-all with the title dadq. 15

In his book, a collection of qane, a great contemporary Ethiopian Orthodox scholar and a qane specialist, Admasu Ğämbäre, ${ }^{16}$ gives a genealogy of the wadla qane teachers. He writes: "When one is asked who started [qane] there are some who say Yoḥannəs Zägäblon born in Wadla; there are some who say Täwanäy or Däqqä Gsțifa born in Goğğam."17 Then Admasu Ğämbäre says that all are right and that there is no reason to quarrel about this. In a short history of Wadla and Goğğam qəne, he states:

First the Wadla party group made as their basis the history that the one who started qəne was Yared. In 146o year of mercy, Yohannəs Gäblawi after realizing that it was Yared who started the qane way asked him: 'Reveal it for me.' He went for a retreat (he hid himself to pray and fast) to a place called Däbrä Tabor which is located between Boräna and Amara Sayənt. It is said that this place was the town of King Yəkunno Amlak. After that the mystery [of qane] together with versification was revealed to him [...]. After that he taught Abba Wäldä Gäbrə’el, (and) Abba Wäldä Gäbrə’el taught Śämrä Ab; Śämrä Ab taught around 1470 year of mercy in the time of Emperor Bä’ədä Maryam. [...] After that Śämrä Ab taught Ləḥib; Ləḥib taught Elyab; Elyab taught Dədq Wäldä Maryam and Täwanäy. At that time Graň invaded [Ethiopia] and the government was disturbed. Täwanäy stayed on an island called Däqqä Asțifa on the island of the Lake

\footnotetext{
14 This was told to me by several qane teachers.

15 See a list of teachers in: Mariye, "The Origin of Qəne and the sources for the Qəne Subject Matter." Such lists are traditionnaly learned by heart by the students in qone schools and (thus) may somehow differ.

16 Tedros Abraha, "Admasu Ğämbäre," in EAe 5 (2014): 221.

17 Admasu Ğämbäre, Mäșhafä Qəne, 10.
} 
Tana. When he was leaving that place, he removed the most important part of Gəəəz grammar (aggäbab); he kept only qəne. Because his master Elyab had already died and because he was not willing to ask his brother Dədq Wäldä Maryam, he abandoned the grammar and started to teach only qəne. That is why there is not much grammar and verb conjugation in the gonğ qəne. But Dədq Wäldä Maryam went to a place called Yäçäräqa in Dawənt and stayed there together with other scholars. He kept the verb conjugation and the grammar and taught. After him six scholars followed him and each of them had the name dadq. Dadq means 'hero.' When one says, 'a hero of mystery' [that is of qəne], one means dadq. At the time of the sixth $d a d q$ the community of students became large and so seven [types of] awa ${ }^{18}$, seven [types of] verb conjugations and seven [types of] grammar were taught there. ${ }^{19}$

In another book, Habtä Maryam Wärqənäh, at one time head of the Holy Trinity cathedral in Addis Abäba (liqä śalțanat), has got one chapter about qəne. ${ }^{20}$ This is what Habtä Maryam says about Yoḥannəs Gäblawi:

The place where he lived was Wällo, in Amara Sayənt, in the town of Däbrä Tabor. He taught many people. But the one who became a role model or who was his successor was a monk called $A b b a$ Wäldä Gäbrə’el. $A b b a$ Wäldä Gäbrə’el taught Śämrä Krəstos; he is also called Śämrä Ab. Śämrä $\mathrm{Ab}$ taught having expanded his school, he took more students. He even taught Emperor Bä’dä Maryam. [...] This Śämrä Ab taught Ləhib and Elyas. Elyas taught Täwanäy and Dədq Wäldä Maryam. Täwanäy became the father of the gonğ way; Dədq Wäldä Maryam became the role model for the wadla way. The qəne bet or the difference in the [qәne] way began at that time. It was the time of war, the [16th century Muslim] Gran invasion, so there was not much communication among them. Therefore, Täwanäy's disciples made the qəne difficult and the grammar (aggäbab) short. But because Dədq Wäldä Maryam continued to teach and kept his position, (he) managed to keep the way of qəne and the principles of grammar (aggäbab). Because he was known by his name, those who continued his teachings were called 'dədq' and continued teaching. This is

18 It is a general study of the Gə`əz grammar.

19 Ibid., 10-11.

$20 \quad$ Habtä Maryam Wärqənäh, Țəntawi Yä-Ityopya Sər’atä Təmhərt [The Ancient Educational System of Ethiopia] (Addis Abäba: Bərhanənna Sälam Qädamawi Haylä Śəllase Mattämiya Bet, 1970/71), 172-211. 
why, being called the wadla qəne or grammar (aggäbab), it is praised and is called after them. In this way, the history tells about seven Dədq who taught the wadla way. However, the last dədq taught Dədq Wäldä Maryam. Dədq Wäldä Maryam taught Ma`əbäl Wäldä Ḥəywät Meç̌a. Ma‘əbäl Wäldä Həywät taught Aläqa Getahun Gete Gämora Mika’el Däbr. After that, however, one teacher started mixing the wadla grammar with the gong and the wašära, due to his desire of not being an ignorant in one of them $[\ldots]$. When welook at the issue from the distance and study it deeply, there is no doubt that the [first] qane composer was Yared. ${ }^{21}$

These two accounts somehow differ. According to Habtä Maryam Wärqənäh, "one teacher started mixing the wadla grammar with the gonğ and the wašära." As for Admasu Ğämbäre "at the time of the sixth dadq the community of students became large and so seven [types of] awağ, seven [types of] verb conjugations and seven [types of] grammar were taught." How to interpret this? Further studies are needed to answer these questions.

For the time being I shall describe the present situation of teaching qane in some parts of Wadla where the first qəne teacher, Yoḥnnəs Zägäblon Gäblawi, is said to be born, at least by Admasu Ğämbäre. I shall now present qəne teachers whom I met during a visit in some churches around Kon, in November $2009 .{ }^{22}$ Before leaving Addis Abäba, I had asked in a hurry some advice about some names of qane teachers and places in Wadla to the regretted Ethiopian Orthodox scholar Abba Säyfä Śəllase (d. 2010 ${ }^{23}$ who had only time to tell me about two places: Abdiqon Giyorgis ${ }^{24}$ and Yänäğğa Mika’el and its qəne teacher Täkkalləňň Mängäša. Some people working for the diocese in Waldiya and in $\mathrm{Kon}^{25}$ also gave us the names of some qane teachers teaching there. We slept in Gašäna. ${ }^{26}$ Then we visited people working for the Ethiopian Orthodox Church

21 Ibid., 174-175.

22 I was accompanied by Magda Krzyzanowska who also made some interviews with the qane teachers; I want to thank her very cordially for her translations of the interviews from Amharic and also for helping me in finalizing this article, especially for the translation of some texts (cf. notes 17 and 20) and for the transcription of Amharic proper names and terms according to the Encyclopaedia Aethiopica.

23 Amsalu Tefera, "Säyfä Śəllase Yoḥannəs," in EAe 5 (2014): 506-507.

24 The village of Abdiqon Giyorgis lies on the way from Wäldiya to Gašäna, in Douftsi Hamousit. Ege, North Wälo, map 58 . You must turn to the left, for about $5 \mathrm{~km}$, then walk half an hour (or all the way by $4 \times 4$ ). The place is known as a famous traditional school, also for qane. In 2009, I was told that no teacher of the traditional schools was left there but I could not check.

25 URL: http://www.maplandia.com/ethiopia/amhara/north-wello/kon/ (13.05.2019).

26 Gašäna is a crossing place: coming from Wäldiya you can turn to the right to reach Lalibäla; 
in Wägäl Țena town, the administrative centre of the present Dälanta wäräda. ${ }^{27}$ Then a list of teachers and places was established to be visited around Kon.

\section{$2 \quad$ Field Research in the Wadla Region}

\subsection{Qane Teachers near Kon}

Near Kon, the first qone teacher we met ${ }^{28}$ was Märigeta ${ }^{29}$ Hzra Bərhanu, a blind man, at Yädəhun Mädhane 'Aläm church. ${ }^{30} \mathrm{He}$ was born in 1944 E C 31 in Asgağä village (a three-day walk from there), where he began his traditional education in Tädbabä Maryam church in which he graduated. He first studied $\operatorname{dag}{ }^{w} a^{32}$ and then qəne, for five years, with Märigeta Gäbrä Mäsqäl ${ }^{33}$ (d. 1986 EC). Then he taught qane in Wämbär Zaragaw for four years. From 1971 EC he began to teach qane in his present place. Before him, there was here a zema teacher, Märigeta Kiros, but no qəne teacher. Azra Bərhanu was graduate in wašära and wadla qəne; and his teacher Gäbrä Mäsqäl knew three qəne styles: wašära, wadla and gonğ. At that time, Đzra Bərhanu was teaching wašära sämənna wärq (that is "wax and gold" with literal and figurative or "hidden" meanings ${ }^{34}$ ). He said that there is not much difference between the wadla and wašära qane and that they are almost the same, which surprised me. ${ }^{35}$

straight you go to Däbrä Tabor; and left to Kon. URL:http://www.maplandia.com/ethiopia/ amhara/north-wello/kon/\#map (13.05.2019).

27 Wägältena, also known as Wägäl Ṭena, is located in the Däbub Wällo Zone of the Amhara Region, with an estimated total population of 7,205 in 2005 . It was the main city of the former Wadla Dälanta awrağğa. Situated on the recently constructed main road between Dässe and Lalibäla via Kone and Gašäna, Wägältena is expected to become a communication link between these historical places.

28 We began to visit qane schools on 11 November 2009.

29 Evgenia Sokolinskaia, "Märigeta," in EAe 3 (2007): 786.

30 From Kon, we drove by pickup for $14 \mathrm{~km}$ in the direction of Däbrä Tabor, stopped, turned right, and then walked for about $6 \mathrm{~km}$. Ege, North Wälo, map 68.

31 EC refers to the Ethiopian Calendar, with a seven-to-eight-year gap between the Ethiopian and Gregorian calendars. Emmanuel Fritsch and Ugo Zanetti, "Christian calendar," in EAe 1 (2003): 668-672. The liturgical year begins on the 11th (12th on a leap year) of September.

32 With Märigeta Gera Wärq, for five years.

33 Gäbrä Mäsqäl's teacher was Märigeta Ṭəbäbu, a famous teacher (died during the reign of Hayla Śəllase) from Yäğğu who himself was teaching in Gayənt Mägäç̌ Qirqos and who had graduated with teacher Buruk. Bzra showed us a notebook with notes by Märigeta Gäbrä Mäsqäl.

34 Denis Nosnitsin, "Sämənna wärq," in EAe 4 (2010): 507.

35 According to Habtemichael Kidane, the wašära qəne is relatively simple and its meaning can be caught even by someone who is not specialized in qane; the gonğ qane is difficult to 
In November 2009, he had 40 students (and 66 students the year before). ${ }^{36}$ They came not only from the surroundings but also as far as Šäwa, Goğğam and Təgray. At the practical level, in 2009 Azra Bərhanu said that he received a salary of 3 o Birr a month. ${ }^{37} \mathrm{He}$ had some fields for growing crops. His family lived from hand to mouth, but this was not enough to keep the whole family, sometimes, if harvest was bad, daily food became a problem.

As for his students, they got some money from their parents who were farmers to get their food (cereals and grains) bought from the market. They did not go for begging their food, as this is the ancient custom for traditional students of the Ethiopian Orthodox Church, because the neighbours had only little for themselves. Here they received no financial help from the church or diocese.

In the afternoon, we met Mämhar ${ }^{38}$ Nahu Sännay of the church of Giyorgis in Dorära. ${ }^{39} \mathrm{He}$ was born in $1935 \mathrm{EC}$ in Giğğu, around $15 \mathrm{okm}$ from here, where he began his traditional education which he finished in Goğğam. ${ }^{40}$ He studied qəne for six years with Wäldä Mika'el whose teacher was Mämhar Sahlu from Mäqülä who was teaching wašära and gonğ qəne. Then he went for qəne graduation to Goğğam, in Gonğ, where he spent three years. His teacher was Məḥät Şəgge from Walta Maryam in Goğğam who had graduated in Moța Giyorgis. Məhrät Șəgge was teaching gonğ and wašära qəne. Then our teacher went to Gondär to study "the Books."11 After graduation there, he began to teach qane and "the Books" for eight years in Gayənt Zuramba (the place of graduation for zammare, $65 \mathrm{~km}$ from Däbrä Tabor) where he also studied zəmmare, one of

understand due to its profound meaning, using complicated concepts and images, often only understandable to the author; the Gondär qane is characterized by its melancholic mood and is didactic alluding to the teaching of the qane teachers. Habtemichael Kidane, "Qəne," 284. The grammar of the wadla qane is difficult.

$36 \quad$ During my visit the students were absent as they had gone home to help their parents for harvest and were coming back after Epiphany.

37 In January 2009, 10.46 Birr equaled one US-dollar, URL: http://nazret.com/blog/index .php/2009/o1/13/ethiopian_central_bank_depreciates_birr_(13.05.2019).

38 Marie-Laure Derat and Denis Nosnitsin, "Mämhər," in EAe 3 (2007): 713.

39 From Kon, go for $4 \mathrm{~km}$ in the direction of Dälanta, then turn right for $6 \mathrm{~km}$ (rocky road which can be used by pick ups), then walk 45 minutes to Dorära Giyorgis church which is situated down, half way between the plateau and the valley; the interview was made near Balä Ggzi'abəher church, without going down to Dorära, because we met the teacher on the way. Ege, North Wälo, map 68.

40 He also studied zema, $a q q^{w} a q^{w} a m$, New Testament and Old Testament. He studied $d_{\partial g g^{w}} a$ with Wäldä Giyorgis.

41 In Gondär city, with Mämhar Bərhanu, in Bä'ata Maryam church, Old Testament and New Testament, for nine years. 
the five books of liturgical song, or zema. Then he came to teach in the present place. In 2009, he was 67 years old. He was then teaching wašära and gonğ qəne, not wadla qane.

In November 2009, 25 of his students of qane were present, not the usual 45 as some had left to go home and help their family for harvest. During Lent the number of students grows up to fifty. He had no student to study "the Books" with him. In November 2009 (European year), his salary was of 55 Birr a month.

The next day, we took the road in the direction of Arbit and Däbrä Tabor. From Gašäna, after $23 \mathrm{~km}$, the car dropped us on the side of the road and we walked to the right in direction of Wäqeta Maryam church (now in Mäqet wäräda ${ }^{42}$ not in Wadla wäräda), looking for Mämhar Dibäkwəllu Gețu. We met him on the way, near Gabrəel church (that is about half way), as he was going there for a funeral. ${ }^{43} \mathrm{He}$ told us about his life. He was born in Läyamba Mika'el (Lasta), in 1936 (the year when the Italians arrived in Ethiopia, he said) ${ }^{44} \mathrm{He}$ studied wadla qəne in Waro Mika'el (wäräda of Mäqet). His teacher for wadla qəne at Šädaho, Sändära Maryam church was Wase for about one year. Wase's teacher was from Abdiqon Giyorgis, but unfortunately Dibäkwəllu Gețu could not remember his name. ${ }^{45}$ Mämhar Dibäkwəllu's next teacher was in Sämada in Däbrä 'Gnqwä Maryam, Mämhar Gețu Täsämma, ${ }^{46}$ with whom Dibäkwəllu studied some qane of Goğğam for four years. ${ }^{47}$ His first and last teacher with whom he learned all kinds of qane (wadla, wašära, gonğ) for four years was Mämhar Bäträ Wärq ${ }^{48}$ in St. George church in Säne Gäbäya in Sämada, on the way to southern Gondär. Dibäkwəllu, graduated with him in all types of qəne.

42 Mäqet is one of the wäräda in the Amhara Region of Ethiopia, in the North Wällo Zone.

43 From Gašäna, take the direction to Däbrä Tabor for $23 \mathrm{~km}$, then walk to the right to Gabrə’el church where we met the mämhar and made the interview; the walk took less than one hour. In 2019, I was showed a non-asphalt road (for $4 \times 4$ drive) on the right leading down into the valley and reaching very close to the school and church of Wäqeta Maryam.

44 As it is the custom, he studied the Psalter (Dawit) and zema in his village.

45 Dibäkwəllu said that he never heard of the famous Ṭəbäbu of Abdiqon. He only knew that the place was famous with many qane teachers. He remembered the name of one teacher, Däbrä Mäsqäl, who was the teacher of the blind teacher met the day before in Kon and who taught at Betä Yoḥannes (near Kon).

46 Gețu Täsämma was a student of Mämhər Wəbəšät (he could not remember his second name) from Goğğam (he could not remember the exact name of the place).

47 From Gețu Täsämma (who did not know qane well, but knew history well), for about three years, Dibäkwəllu studied the Psalter, Hymns (nägs) and targum (that is the interpretation) of waddase maryam and qaddase maryam.

48 Bäträ Wärq learned from Buruk, a teacher in Dässe (also mentionned the day before by the blind teacher). 
He also said that he went to Sälalo where he studied qəne with the famous Mother Gälanäš. He stayed there only one year and found the gonğ qane there very difficult. Mämhar Dibäkwəllu also studied $a q q^{w} a^{w} q a m$ for three years with Mämhər Ayyälö Märawi at Mäqet, Kurifta Kidanä Məhrät. When we met him in 2009, Dibäkwəllu said that then he was not teaching the wadla qəne, but wašära qәne. When I met him in February 2019 he said that he was teaching different types of qane, including wadla. According to Dibäkwəllu, when we met him in 2009, no one was then teaching the wadla qane in Wadla.

On 13 November 2009, we went to Yänäğğa Mika'el. ${ }^{49}$ The place is historically important for qəne as some say that Yoḥannəs Zägäblon Gäblawi (that is of Gäblaw), the first composer of qəne, was born there. ${ }^{50}$ When we went in 2009, there was no qane teacher. It is also here that taught the famous teacher Täkkalləňň Mängäša (d. 1969), apparently the last qəne teacher in this place (of what we then understood).

We asked the few traditional teachers whom we met about him, ${ }^{51}$ as well as a farmer, Taddäsä Mäkwännən, who had been Täkkalləňň's student. He told us about Täkkalləňň's grand son, Märigeta 'Alämu Yohannəs, living in a nearby village. We decided to visit him. We found him living near the hamlet of Zugära. ${ }^{22} \mathrm{He}$ was a däbtära doing the $a q q^{w} a q^{w} a m$ in church, but he did not teach. He owned some manuscripts, which is quite unusual in a faraway hamlet. He was thirteen years old when his grandfather died and, unfortunately, he told us that he was too young to remember him well.

'Alämu Yohannəs studied with Nahu Sännay and with his father Yoḥannəs in Agiçäw, but he did not study any qane with his grandfather. 'Alämu Yoḥannəs said that Täkkalləňň's wife was Käbäbuš Bäwqätu, the mother of Yoḥannəs. Täkkalləňň Mängäša studied qəne in Goğğam, in Gonğ. Later he "disappeared, became invisible" in the place called Däqqä Gsțifa, which means that he went there to have a spiritual retreat. Then he came back to Wadla, to Abdiqon (the place of his father Mängäša) and later moved to Yänäğ Mika’el. He was buried

49 First by bus (in direction of Kon), and then we walked to the right for about an hour. In 2009 there was no asphalt road, but I was told that there was also a possible access by $4 \times 4$ from the main road from Gašäna to Däbrä Tabor.

50 Märigeta Lə'ul Mälläs, the teacher of $a q q^{w} a q^{w} a m$ we met in Yänäğğa Mika'el, told us that Yohannəs Gäblawi established there the first qəne bet. Today it is a market place (twice a week).

51 With Märigeta Abraham, teacher of zema, with the $a q q^{w} a q^{w} a m$ teacher Läggäsä Gngədaw who spoke on the tradition of the place; and with a nun Ammahoy Alämitu Gəzaw.

$5^{2}$ Probably Zigora between Yänäğğa Mika’el and Arbit, near Qwama village. Ege, North Wälo, map 68. 
in the St. Giyorgis church in Abdiqon where he was born. Apparently, he taught all kinds of qane, including wadla qane. This must be investigated in the future with other interviews about him.

\subsection{Qəne Teachers in Wägäl Tena (Dälanta)}

We also wanted to visit some qəne teachers in Wägäl Ṭena town (Dälanta), ${ }^{53} \mathrm{a}$ town south of Kon. There we went to the church of Mäsqälä Krəstos built in 1987 EC, on top of a hill. In $1995 \mathrm{EC}$, the place was organized as a traditional school. In 2009 Abunä Qerəllos, Archbishop of North Wällo, residing in Wäldiya was responsible of the Wadla region described here.

In 2009, there were two qane teachers and 17 students. The old qane teacher, Gäbrä Ḥanna, was blind. He was born in 1920 EC in Șay Moča (Dälanta), ${ }^{54}$ on the way to Iğğu, three hours walk from his present place. Then he went to Lasta and later to Wadla. He studied qəne for one year with Mämhər Märawi Wärqənäh ${ }^{55}$ (d. $1968 \mathrm{EC}$ ), a qəne graduate from Dima Giyorgis (Goğğam) who lived in Waro Mika’el (Lasta) and later in Dälanta Ṭana Iyäsus. He graduated with him. Gäbrä Ḥanna taught sämənna wärq qəne and he did not know the wadla qəne.

Then, in the same school, we had a long talk with another qane teacher who was young, Yəbabe Fäqadä (apparently, since that time, he left the place). He was born in 1969 EC in Yäğğu, near Kom. He began to study qəne with Mämhər A’əmro (himself graduated from Mämhar Yared Šifärraw from Čăgode) in Yänäğğa Mika’el in 1985 Ec, for one year. Then he studied in Gännätä La’ul near Wäldiya with Mämhər A’əmärä Mäššǎša (who also graduated by Yared Šifärraw in C̣̆ägode), for two years. He became assistant teacher (zärafi $)^{56}$ of A’əmärä Mäššăša. Then, he went to Ḥayq Hsțifanos monastery, for one year and half, and studied qəne by Mämhər Məśraq. He also studied in Däbrä Sina (Gayənt) with Mämhar Fərew. He graduated in qəne in 1995 Ec by Bishop Qerəllos of Wäldiya

53 We found no direct public transportation from Kon thus we had to go to Däsie and take a bus from there (leaving at about $5^{-6}$ am) to Dälanta.

54 There he first studied the Psalter.

55 Märawi Wärqənäh was teaching the sämənna wärq qәne. He graduated in goğğam qəne in Dima Giyorgis which is a place famous for sämanna wärq qane and commentaries of the Old Testament and the New Testament. Märawi Wärqənäh's teacher was Mämhər Yared (died 1944 EC) also from Dima Giyorgis. Then Märawi Wärqənäh went to Dälanta Ṭana Iyäsus (where he spent eighteen years and died); there Gäbrä Hanna studied with him for ten years. After that, Gäbrä Hanna went back to his native village and taught from 1951 and went to the present place (in Dälanta) in 1995 EC.

$5^{6}$ The advanced student of the school of qane (qane bet) is permitted to teach the beginners and lecture qəne until his graduation day as qəne master. Habtemichael Kidane, "Qəne bet," 285 . 
who knows different types of qane, including wadla qəne. Then Bishop Qerəllos employed him to teach qəne in the church school of Mäsqälä Krəstos.

In 2009 both teachers had a good salary in comparison with some others in that time. In 2009 Yəbabe Fäqadä received ${ }_{125}$ Birr a month and the old teacher Gäbrä Hanna 300 Birr. On the other side, ten on seventeen students were receiving 95 Birr a month. This place was considered as a boarding school and a kind of 'high school' of qone which explains the rather high salaries in a rather isolated place.

These were the teachers I met and interviewed in 2009. We heard of other qane schools in the area of Wadla but we were not able to visit them, because we had not enough time and no private transportation. For example, near Wägäl Țena, the names of two other qane teachers were given, Mämhər Fəssəḥa C̣̆anne and Mämhər Bäyyänä in the large church (däbr) of Babba Näakkwəto Läab. And we heard about the C̣̆äw Quțr qane school near the däbr of Mika'el, near Wägäl Ṭena town (Dälanta), on the way from Kon to Wägäl Ṭena in Dälanta.

\section{3}

\section{Conclusion}

In 1971/72 EC Admasu Ğämbäre was still putting Wadla in first position on his list of the main centres for learning qane in Ethiopia. ${ }^{57}$ In November 2009, after my trip in Wadla, Mämhər Gäbrä Wäld (d. 2016), a well-known qəne teacher in Bäcata church in Addis Abäba (including of wadla qane), told me, after I told him that the teaching of wadla qane in Wadla had somehow disappeared: "I don't know what you have found in Wadla now, but in my time there were teachers of wadla qəne in Wadla."

During my visit in Wadla in 20o9, only two of the märigeta we met, Hzra Bərhanu and Dibäkwəllu Gețu, had studied wadla qəne but they did not actually teach it at the time we met them, thus their knowledge of wadla qane was somehow lost. Then it seemed to me that, in that time, wadla qane (the root of qane) had much decreased and was not taught in a systematic way in the part of Wadla which I have visited. This was confirmed to me by Mämhər Fəssəḥa

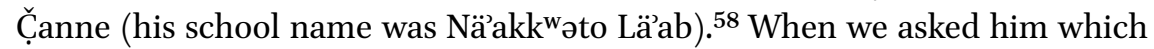
teachers were still teaching wadla qane in Wadla, he answered none, except sometimes Azra Bərhanu, just mentioned.

57 Admasu Ğämbäre, Mäșhafä qəne, 10. Cf. Habtemichael Kidane, "Qəne," 284-285 and Habtemichael Kidane, "Qəne bet," 286.

58 We called him from Addis Abäba on 3 February 2017 with Dr. Mersha Alehegne of Addis Abäba University whom I want to thank here for his help. 
Mämhər Fəssəḥa C̣̆anne studied wadla qəne from Mämhər Däbrä Maryam, from Mämhar Kaśśaye Ḥawaz (who lived in C̣̆äw Quțər Mika’el) and from Mämhər Wäldä Tənsa’e (who lived in C̣̆ana Mika’el), all from Wadla. He graduated in wadla qəne with Mämhər Hawaz in Näakkwºto Lä’ab. He also went to Goğğam to study gonğ qəne with Mämhər Harägäwäyn Kənde in Wägära Guntər in the church of Gäbrä Mänfäs Qəddus (not far from Gonğ), where he graduated in gonğ qane. In February 2017, he was teaching gonğ qane in Dässe (in Mänbärä Șähay Täklä Haymanot church) not wadla qəne, which means that his knowledge of wadla qone was not transmitted, as it is also unfortunately the case for other teachers knowing wadla qəne.

Mämhər Fəssəha C̣̆anne also gave me the following information. In Näak$\mathrm{k}^{\mathrm{w}}$ əto Lä’ab, the genealogy of qəne teachers is as follows: the first teacher was Mämhər Wäldä Giyorgis who gave his chair to Śənnä Giyorgis, then to Wəbe Gäbrä Śəllase, Bərəlle Wube, Bälay Gobäze, Mär'awi, Gäbrä Maryam gave it to Hawaz, and then to himself, Fəssəha C̣̆anne.

When Fəsseha C̣̆anne was a student, the following qane teachers were famous in Wadla: Wäldä Tənsa'e (in C̣̆ana Mika'el), Gəçäw (in Yäç̣äräqa Giyorgis) and Gäbrä Mäsqäl (from Sayənt Tängobaläl Mädəh) who used to teach wadla qəne in Tängobaläl Mädḩane 'Aläm church (in Sayənt). Fəssəḥa C̣̆anne named another famous teacher of wadla qəne, Yəheyyəs (in Boräna Mäkanä Sälam in Kidanä Məhrät church, in Wällo), still alive in 2017, but very old and not teaching any longer.

According to Fəssəha Ç̣anne, the famous centres to teach wadla qəne in Wadla were (still during the imperial period): Betä Yohannəs (with the famous teacher Gäbrä Mäsqäl), Yänäğğa Mika’el (with the famous teacher Täkkalləňň Mängäša who also had a great knowledge of $\operatorname{dagg}^{w} a$ ) and Betä Hor Giyorgis where the famous Gäbre was teaching. In February 2017 there was no more qane teaching in these places.

Mämhər Fəssəḥa C̣̆anne also said that, in 2017, in his original place of Babba

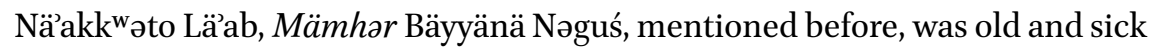
and not teaching wadla qane any longer and that there was no more teacher of qəne also in C̣̆äw Quțr qəne school in St. Michael church (also mentioned before) where the last teacher was Hawaz. Hawaz taught wadla qəne. This interview with Fəssəha C̣̆anne shows the decrease of the teaching of wadla qəne in Wadla recently. About Täkkalləňň Mängäša and the other famous teachers named in this article, further investigations should be made.

At the same time, also in February 2017, I heard from Dr. Mersha Alehegne in Addis Abäba that a group of people in the town of Wäldiya wanted to revive wadla qəne, with a committee under Archbishop Qerəllos and with the collaboration of the university of Wäldiya and of the local governement. During my 
visit in Wäldiya in January 2019, I heard the same information, also with the support of the newly appointed Bishop Erməyas. Further and more systematic studies are needed to complete my present comments on the situation of wadla qane, its teaching and the situation of the few professors still teaching it in Wadla and elsewhere in Ethiopia.

Nowadays, in Ethiopia, wadla qane is still taught, but by very few teachers. ${ }^{59}$ Wadla qane is said to be more complex and complicated to compose than other types of qane. As mentioned before, the wadla qane is particularly difficult on account of its composition and interpretation, because it employs many equivocal words, allusions and allegoric figures. This explains partly why there are very few specialists of wadla qane still composing it today in Ethiopia. Also the deep meaning of the wadla qəne, more than other types of qane, is very difficult to be understood by the audience when it is sung in church because people are less learned than in the past in this specific type of qəne, and also in qəne and in Gəəəz language in general. And today people request qəne which can be understood easily such as wašära qane.

Traditional education of the Ethiopian Orthodox Church has been taught for centuries and is still taught, but for how many years more? Now what about global interconnections of the Ethiopian Orthodox Church traditional education and qəne? Apparently external influences are none. In reality, modern life with a lot of western habits in Ethiopia has a strong and negative impact on these Christian traditional fields in Ethiopia today. It is also a fact that, nowadays, less young people dragged by modern life are interested to study Gəəəz and traditional education, including qane. The question of the decreasing number of teachers and students and the reasons for that should also be discussed. For all the questions about this topic, the causes must be analysed and answers must be found, as qane and wadla qane, being deeply part of the traditional oral teaching of the Ethiopian Orthodox Church, can be seen as intangible patrimony not only in Ethiopia but also in the history of church at large.

Other factors must be analysed. Nowadays in Ethiopia, and for many decades already, foreign influences came from the western countries, including from other churches through their missionaries's activity. For example, the missionaries, especially from the Protestant traditions, do put forward modernity and technological progress, often without respecting the traditional life and teaching of the Ethiopian Orthodox Church, and sometimes also mocking not to say showing despise for the traditional education of the Ethiopian Orthodox Church. One might perceive these factors as somewhat negative. 
One cannot stop modernity as well as western influence in Ethiopia including in the life of the Ethiopian Orthodox Church. Then, what to do to keep this traditional education (including qəne) alive for today and for the next generations? How to keep something of this traditional qəne teaching, which is an oral teaching thus fragile and difficult to keep? In this case, modern technichal means could be very useful in order to safeguard what can be safeguarded, for example through recording and making videos.

It is now the last moment to think and to organise recording of the best teachers as well as to publish materials that they have preserved for example in their notebooks of grammar while they were students, or what they learned and remember from their teachers, some being famous and their names must be remembered as well. It is time to write their history, or at least what is being remembered today about them. Ideally all such material should then be put on a website, in order to be shared by the largest number of people (Ethiopian Orthodox Christians, scholars, etc.).

At the 16th International Conference of Ethiopian Studies in Trondheim Norway in July 2007, I presented a paper to challenge people to make specific studies on traditional education of the Ethiopian Orthodox Church in Ethiopia, including on qane. ${ }^{60}$ In this paper I wish to challenge people on wadla qəne in Wadla. Here I present this paper as a little act of resistance in time and space, in fact a shout in the middle of the modern wilderness as qəne, wadla qone and the teaching of Gəəəz are somehow, slowly, step by step, disappearing in Ethiopia.

All together we have to think seriously what to do, how to do it, how to answer the question of the future of traditional education, including qane and wadla qane, and how to save all this. The first step would be to write down in detail all the rules of qəne, including wadla qəne (especially its grammar, aggäbab), and also verbs, in a systematic and scholarly way. ${ }^{61}$

In the case of traditional education and qane teaching in a globalized context, western scholars who really appreciate traditional education as well as qane, together with Ethiopian scholars, could find ways to keep it alive and to teach it (also on Internet). In the case of our topic, qane, all the rules of the different types and schools of qane should be written down in a very precise and

6o Christine Chaillot, "Traditional Teaching in the Ethiopian Orthodox Church. Yesterday, Today and Tomorrow," in Research in Ethiopian Studies. Selected Papers of the 16th International Conference of Ethiopian Studies, Trondheim July 2007, ed. Harald Aspen et al. (Wiesbaden: Harrassowitz, 2010), 240-247.

61 See Muluken Andualem Siferew, Comparative Classification of Ge'ez Verbs in the Three Traditional Schools of the Ethiopian Orthodox Church (Aachen: Shaker Verlag, 2013). See e.g. also: Hiruie Ermias, The Issues of 'Aggabāb (Classic Gəə̀z Grammar) According to the Tradition of Qəne Schools, Ph.D. Dissertation, Universität Hamburg 2018. 
detailed way. All this material should be published and shared through printed and digital media. This type of collaboration would be a way to save what can be saved of the Ethiopian Orthodox treasure of qane for the coming generations. This would also configure the global interconnections and local identities in a positive way.

Some of our present considerations show that it is very urgent to make interviews and to record at least the very best teachers before they pass away and before their knowledge and traditional way of teaching is lost. For the last decade I have repeated this, unfortunately without any tangible results. If the teaching of qane (and also of traditional teaching of the Ethiopian Orthodox Church at large) is not preserved properly, soon it can be lost, and forever. This is my worry. It should be our common worry.

\section{List of References}

Admasu Ğämbäre. Mäșhafä Qəne (Zəkrä Liqawənt) [The Book of the Qəne (The Memory of the Scholars)]. Addis Abäba, 1970/71.

Amsalu Tefera. "Säyfä Səllase Yoḥannəs." In EAe 5 (2014): 506-507.

Brita, Antonella. "Yared." In EAe 5 (2014): 26-28.

Chaillot, Christine. "How to Preserve the History of the Oral Traditional Education of the Ethiopian Orthodox Church in Ethiopia: Qəne teachers in Wašära, Gonğ, Sälalo and elsewhere in Goğğam." In African Studies. Forging New Perspectives and Directions, edited by Nina Pawlak, Hanna Rubinowska-Anioł and Izabela Will, 199-215. Warszawa: Elipsa, 2016.

Chaillot, Christine. The Ethiopian Orthodox Tewahedo Church Tradition. A Brief Introduction to Its Life and Spirituality. Paris: Inter-Orthodox Dialogue, 2002.

Chaillot, Christine. "Traditional Teaching in the Ethiopian Orthodox Church. Yesterday, Today and Tomorrow." In Research in Ethiopian Studies. Selected Papers of the 16th International Conference of Ethiopian Studies, Trondheim July 2007, edited by Harald Aspen, Birhanu Teferra, Shiferaw Bekele and Svein Ege, 240-247. Wiesbaden: Harrassowitz, 2010.

Chernetsov, Sevir. "Traditional Christian education." In EAe 2 (2005): 228-230.

Damon-Guillot, Anne. "Zema." In EAe 5 (2014): 174.

Derat, Marie-Laure, and Denis Nosnitsin. "Mämhər." In EAe 3 (2007): 713-714.

Ege, Svein. North Wälo 1:100,ooo. Topographic and administrative map of North Wälo Zone, Amhara Region, Ethiopia. Trondheim: Norwegian University of Science and Technology, 2002.

Ezra Gebremedhin. "Mästägabə’." In $E A e ~ 3$ (2007): 857-858.

Fritsch, Emmanuel. "Qəddase." In EAe 4 (2010): 271-275. 
Fritsch, Emmanuel, and Ugo Zanetti. “Christian calendar." In EAe 1 (2003): 668-672.

Getatchew Haile. “Gə`əz literature.” In EAe 2 (2005): 736-741.

Habtä Maryam Wärqənäh. Ţntawi Yä-Ityopya Sər'atä Təmhərt [The Ancient Educational System of Ethiopia]. Addis Abäba: Bərhanənna Sälam Qädamawi Haylä Səllase Mattämiya Bet, 1970/71.

Habtemichael Kidane. "Arba’ət." In EAe 1 (2003): 317.

Habtemichael Kidane. “Doggwa." In EAe 2 (2005): 123-124.

Habtemichael Kidane. "Mäṣhaf bet." In EAe 3 (2007): 834.

Habtemichael Kidane. "Qəne." In EAe 4 (2010): 283-285.

Habtemichael Kidane. “Qəne bet." In EAe 4 (2010): 285-286.

Habtemichael Kidane. "Somä dəggwa." In EAe 4 (2010): 691-692.

Habtemichael Kidane. "Zəmmare." In EAe 5 (2014): 175-176.

Heldman, Marilyn. "Psalter." In EAe 4 (2010): 231-233.

Hiruie Ermias, The Issues of 'Aggabāb (Classic Gàzz Grammar) According to the Tradition of Qəne Schools, Ph.D. Dissertation, Universität Hamburg 2018.

Kaufman-Shelemay, Kay. "Aqwaqwam." In EAe 1 (2003): 293.

Muluken Andualem Siferew, Comparative Classification of Ge'ez Verbs in the Three Traditional Schools of the Ethiopian Orthodox Church. Aachen: Shaker Verlag, 2013.

Munro-Hay, Stuart. "Christianity." In EAe 1 (2003): 717-723.

Nosnitsin, Denis. "Sämənna wärq." In EAe 4 (2010): 507-509.

Sokolinskaia, Evgenia. "Märigeta." In EAe 3 (2007): 786.

Sokolinskaia, Evgenia. "Wadla." In EAe 4 (2010): 1067.

Tedros Abraha. “Admasu Ğämbäre.” In EAe 5 (2014): 221. 